\title{
Innate Defense against Fungal Pathogens
}

\author{
Rebecca A. Drummond ${ }^{1}$, Sarah L. Gaffen ${ }^{2}$, Amy G. Hise ${ }^{3,4}$, and Gordon D. Brown ${ }^{1}$ \\ ${ }^{1}$ Aberdeen Fungal Group, University of Aberdeen, Aberdeen AB25 2ZD, United Kingdom \\ ${ }^{2}$ Department of Medicine, Division of Rheumatology and Clinical Immunology, University of Pittsburgh, \\ Pittsburgh, Pennsylvania 15261 \\ ${ }^{3}$ Department of Pathology, Case Western Reserve University, School of Medicine, Cleveland, Ohio 44106 \\ ${ }^{4}$ Department of Medicine, Louis Stokes Veterans Affairs Medical Centre, Cleveland, Ohio 44106 \\ Correspondence: r01rad0@abdn.ac.uk
}

Human fungal infections have been on the rise in recent years and proved increasingly difficult to treat as a result of the lack of diagnostics, effective antifungal therapies, and vaccines. Most pathogenic fungi do not cause disease unless there is a disturbance in immune homeostasis, which can be caused by modern medical interventions, diseaseinduced immunosuppression, and naturally occurring human mutations. The innate immune system is well equipped to recognize and destroy pathogenic fungi through specialized cells expressing a broad range of pattern recognition receptors (PRRs). This review will outline the cells and PRRs required for effective antifungal immunity, with a special focus on the major antifungal cytokine IL-17 and recently characterized antifungal inflammasomes.

$\mathrm{H}$ uman fungal pathogens are responsible for more than a million life-threatening infections annually, which can be associated with mortality rates reaching 95\% (Brown et al. 2012). Fungal infections are difficult to treat and control because of rising problems of antifungal drug resistance and the lack of diagnostics, novel antifungal drugs, and vaccines. Fortunately, the majority of pathogenic fungi are opportunistic pathogens (Table 1) and, as such, do not normally cause disease unless there are alternations in immune defense. The use of immunosuppressive drugs, the human immunodeficiency virus (HIV) epidemic, and modern clinical interventions result in such alternations and have contributed substantially to the recent increases of systemically infected patients. Fungi also cause nonlethal skin and mucosal infections that are equally difficult to treat and often recurring.

The innate immune system is the first line of defense against pathogens and broadly protects against invading microorganisms. Genetically inherited receptors, called pattern recognition receptors (PRRs), are used by innate cells for recognition of conserved pathogen-associated molecular patterns. Signaling downstream from PRRs activates cellular responses and killing mechanisms, and also helps initiate and shape adaptive immune responses. Adaptive immunity, unlike innate, is activated by specific antigens recognized by noninherited

Editors: Arturo Casadevall, Aaron P. Mitchell, Judith Berman, Kyung J. Kwon-Chung, John R. Perfect, and Joseph Heitman Additional Perspectives on Human Fungal Pathogens available at www.perspectivesinmedicine.org

Copyright (C) 2015 Cold Spring Harbor Laboratory Press; all rights reserved; doi: 10.1101/cshperspect.a019620 Cite this article as Cold Spring Harb Perspect Med 2015;5:a019620 
R.A. Drummond et al.

Table 1. Species of pathogenic fungi that cause disease in humans, the barrier tissue breached and organs infected, and the PRRs needed for protective immunity

\begin{tabular}{|c|c|c|c|c|}
\hline & Selected disease(s) & $\begin{array}{c}\text { Barriers } \\
\text { breached/site } \\
\text { of infection }\end{array}$ & $\begin{array}{l}\text { Selected PRRs } \\
\text { involved in } \\
\text { protective } \\
\text { immunity }\end{array}$ & Selected references \\
\hline \multicolumn{5}{|l|}{ Ascomycota } \\
\hline Candida albicans & $\begin{array}{l}\text { Disseminated } \\
\text { candidiasis } \\
\text { Vulvovaginal } \\
\text { candidiasis } \\
\text { Mucosal candidiasis }\end{array}$ & $\begin{array}{l}\text { Blood, kidneys, } \\
\text { brain, heart } \\
\text { Vagina } \\
\text { GI tract, oral } \\
\text { mucosa }\end{array}$ & $\begin{array}{l}\text { TLR-2/TLR- } \\
\quad 4 / \text { TLR-6 } \\
\text { Dectin-1 } \\
\text { Dectin-2 } \\
\text { CR3, DC-SIGN }\end{array}$ & $\begin{array}{l}\text { Ferwerda et al. } 2009 \\
\text { Saijo et al. } 2010 \\
\text { Wells et al. } 2008\end{array}$ \\
\hline Candida glabrata & $\begin{array}{r}\text { Disseminated } \\
\text { candidiasis }\end{array}$ & $\begin{array}{l}\text { Blood, kidneys, } \\
\text { brain, heart }\end{array}$ & Mincle, MR & \\
\hline Aspergillus fumigatus & $\begin{array}{l}\text { Invasive pulmonary } \\
\text { aspergillosis } \\
\text { Allergic } \\
\text { bronchopulmonary } \\
\text { aspergillosis }\end{array}$ & $\begin{array}{l}\text { Lung, blood } \\
\text { Lung }\end{array}$ & $\begin{array}{l}\text { TLR-9/TLR-3 } \\
\text { Dectin-1, } \\
\quad \text { Dectin-2 } \\
\text { CR3 } \\
\text { DC-SIGN }\end{array}$ & $\begin{array}{l}\text { Ramirez-Ortiz } \\
\quad \text { et al. } 2011 \\
\text { Werner et al. } 2009 \\
\text { Sainz et al. } 2012\end{array}$ \\
\hline Pneumocystis carinii & Pneumonia & Lung & Dectin-1 & Saijo et al. 2007 \\
\hline $\begin{array}{l}\text { Blastomyces } \\
\text { dermatitidis }\end{array}$ & $\begin{array}{l}\text { Blastomycosis } \\
\quad \text { (pneumonia) }\end{array}$ & Lung & $? ?$ & Wüthrich et al. 2011 \\
\hline $\begin{array}{l}\text { Histoplasma } \\
\text { capsulatum }\end{array}$ & $\begin{array}{l}\text { Histoplasmosis } \\
\text { (pneumonia) }\end{array}$ & Lung & $? ?$ & Wüthrich et al. 2011 \\
\hline $\begin{array}{c}\text { Paracoccidioides } \\
\text { brasiliensis }\end{array}$ & Paracoccidioidomycosis & Lung & TLR-2/TLR-4 & Loures et al. 2011 \\
\hline $\begin{array}{l}\text { Coccidioides immitus } \\
\text { Coccidioides } \\
\quad \text { posadasii }\end{array}$ & $\begin{array}{l}\text { Coccidioidomycosis } \\
\text { (Valley fever) }\end{array}$ & Lung, blood & Dectin-1 & $\begin{array}{l}\text { Viriyakosol et al. } \\
2013\end{array}$ \\
\hline Fonsecaea pedrosi & Chromoblastomycosis & Skin & $\begin{array}{l}\text { TLRs } \\
\text { Mincle }\end{array}$ & $\begin{array}{c}\text { Da Glória Sousa } \\
\text { et al. } 2011\end{array}$ \\
\hline \multicolumn{5}{|l|}{ Basidiomycota } \\
\hline $\begin{array}{l}\text { Cryptococcus } \\
\text { neoformans }\end{array}$ & $\begin{array}{l}\text { Cryptococcosis/ } \\
\text { cryptococcal }\end{array}$ & Lung, brain/CNS & $\begin{array}{l}\text { MR } \\
\text { TLR-2 }\end{array}$ & Dan et al. 2008 \\
\hline Cryptococcus gattii & meningitis & & CR3 & \\
\hline Trichosporon rubrum & Onychomycosis & Skin/nails & ?? & \\
\hline $\begin{array}{l}\text { Malassezia } \\
\text { sympodialis }\end{array}$ & $\begin{array}{l}\text { Atopic } \\
\quad \text { dermatitis } \\
\text { Atopic eczema }\end{array}$ & Skin & $\begin{array}{l}\text { Mincle } \\
\text { Dectin-2 }\end{array}$ & Ishikawa et al. 2013 \\
\hline
\end{tabular}

CNS, central nervous system; CR3, complement receptor 3; GI, gastrointestinal; MR, mannose receptor; PRRs, pattern recognition receptors; TLR, Toll-like receptor.

T-cell/B-cell receptors and has a faster response time with each subsequent challenge (immune memory) (Wüthrich et al. 2012).

The vast predominance of fungi in the environment results in continual human exposure. It is estimated that we inhale several hundred Aspergillus fumigatus spores a day (Rivera et al. 2011), and many humans are also colonized with commensal fungi (e.g., Candida albicans) (Iliev et al. 2012). For this reason, our innate system is equipped to recognize fungal particles and maintain commensal relationships, but also destroy the pathogenic fungi that we are exposed to. This review will outline the cells and recognition receptors in innate antifungal immunity, with a special focus on IL-17 defenses and inflammasomes, both recently identified as major players in antifungal defense. 


\section{CELLS AND BARRIERS}

\section{Cells of the Innate Immune System}

Cells considered part of the innate immune system are characterized by the presence of inherited receptors with broad specificity (see next section) and a rapid response time. This section will discuss the predominant cell types used for antifungal defense: neutrophils, macrophages, dendritic cells (DCs), natural killer (NK) cells, innate-like lymphocytes, and epithelial cells (ECs). However, it is important to appreciate that there are several other cellular populations that may contribute in antifungal responses, although they remain poorly characterized or unstudied in the context of fungal infections.

\section{Neutrophils}

Neutrophils are highly phagocytic granulocytic polymorphonuclear cells that have been well characterized as a result of their importance in antimicrobial immunity. The classic mechanism of killing by neutrophils is through the production of reactive oxygen species (ROS), which kill phagocytosed microbes when the granules that contain them fuse with the phagosome. Nonoxidative mechanisms include the release of neutrophil-specific degrading enzymes, elastase and cathepsin-G, which were shown to be nonredundant in A. fumigatus immunity (Tkalcevic et al. 2000). Other methods of killing include the formation of neutrophil extracellular traps (NETs), external lattices made up of DNA, histones, and antimicrobial proteins (Byrd et al. 2013). NETs have been described in human neutrophils exposed to A. fumigatus (McCormick et al. 2010), C. albicans (Urban et al. 2006), and Cryptococcus neoformans (Urban et al. 2009). The relative importance of NETs in vivo has still to be determined, although a key component of NETs, calprotectin, was recently shown to have efficacy against $C$. albicans in vivo, and animals deficient in calprotectin were more susceptible to infection (Urban et al. 2009).

Neutrophils have also been shown to play detrimental roles during fungal infection through immunopathology. Neutrophil-depleted animals were shown to survive for longer and have lower burdens of $C$. neoformans following pulmonary infection (Mednick et al. 2003), whereas $\mathrm{CCR} 1^{-/-}$animals, which have defective neutrophil recruitment to the kidney during disseminated candidiasis, had improved survival and outcome (Lionakis et al. 2012). This may, however, not translate to human medicine in which neutrophil frequency and function appear to be hugely important for host defense. A reduction in circulating neutrophils is cited as a high risk factor for developing invasive candidiasis (Byrd et al. 2013), and chronic granulomatous disease patients, whose neutrophils are unable to make ROS, are more likely to be diagnosed with invasive aspergillosis (De Luca et al. 2012).

\section{Monocytes/Macrophages}

Monocytes are blood-borne cells that differentiate into macrophages within tissues, which they infiltrate following an inflammatory signal. Once within tissues, macrophages further develop into a distinct functional phenotype, which is determined by the cytokine milieu. Proinflammatory cytokines, particularly interferon $\gamma($ IFN- $\gamma)$, drive a classically activated (M1) phenotype, whereas anti-inflammatory cytokines (e.g., TGF- $\beta$ ) drive alternatively activated (M2) macrophages (Mosser and Edwards 2008). Macrophage phenotype can have a profound effect on antifungal immunity. In experimental pulmonary cryptococcosis (caused by $C$. neoformans), susceptibility is associated with M2 phenotypes, whereas protective vaccine strains induce M1 cells that correlated with enhanced survival rates to subsequent lethal challenges (Hardison et al. 2012). Macrophages are also able to switch between M1/M2 phenotypes, and this plasticity was recently shown to be crucial in the protection against another respiratory fungal pathogen, Paracoccidioides brasiliensis. Using resistant and susceptible strains of mice, both M1 and M2 cells were shown to control fungal growth, although their protective value was only evident at different stages of infection (Feriotti et al. 2013). 
R.A. Drummond et al.

A recent major development in the field of innate immunology was the demonstration of "trained immunity," a term given to describe short-term immunological memory carried by innate cells (Netea et al. 2011; Netea 2013). Innate cells shown to participate in this phenomenon include NK cells and monocytes. Trained immunity was recently shown to protect against fungal infection; monocytes stimulated in vitro with $\beta$-glucans, a component of fungal cell walls, were shown to protect animals deficient in an adaptive immune system against lethal systemic candidiasis infections, and this protection was attributed to epigenetic reprogramming (Netea et al. 2011; Quintin et al. 2012; Netea 2013).

\section{DCs}

DCs are important innate cells involved in the initiation of immune responses through to the generation of adaptive immunity via antigen presentation (discussed in detail elsewhere in the literature). DCs have attracted particular attention in their potential as effective targets for novel therapeutic and vaccine strategies. Recent studies have shown how use of nonpathogenic yeast (Kiflmariam et al. 2013) and complexes targeting innate antifungal receptors expressed by DCs (Carter et al. 2006; Lipinski et al. 2013) can induce effective antifungal immunity. However, to take full advantage of this novel approach it still needs to be understood which DC subtypes are needed for antifungal protection and the mechanisms involved. DC subtypes are based on phenotype, anatomical location, and other functional characteristics. The different DC subtypes that contribute to antifungal immunity are still being determined, although it has recently been suggested that plasmacytoid dendritic cells ( $\mathrm{pDCs}$ ), typically considered as antiviral cells, may play a protective role to pulmonary fungal pathogens. Animals resistant to $P$. brasiliensis infection were shown to generate a mixed lung DC population, including pDCs, which susceptible mice lacked (Pina et al. 2013). Furthermore, animals depleted in pDCs were shown to be hypersusceptible to invasive aspergillosis, which correlated to the toxicity and pro- tective cytokine responses exerted against the fungi by pDCs in vitro (Ramirez-Ortiz et al 2011). In addition to understanding the roles of functional subtypes of DCs, it is also important to understand how fungi interact with DCs once engulfed. For example, C. gattii is efficiently killed by DCs; however, it does not appear to stimulate proper maturation, and thus immunity is compromised and may explain the ability of this organism to infect otherwise healthy hosts (Huston et al. 2013).

\section{NK Cells}

NK cells are primarily known for their antiviral and -tumor properties, for which they were first identified. NK cells in both mice and humans have been described to have antifungal activity against a range of fungi including $C$. albicans, A. fumigatus (Schmidt et al. 2013b), C. neoformans (Islam et al. 2013), Pneumocystis murina (Kelly et al. 2013), and P. brasiliensis (Longhi et al. 2012). NK cells exert their effect through the direct killing of yeast using perforin, killing infected host cells, and secretion of proinflammatory cytokines (Schmidt et al. 2013b). However, the role of $\mathrm{NK}$ cells is complicated and poorly understood; many articles have suggested influential roles of NK cells on other cell types (reviewed extensively by Schmidt et al. 2013b), and a further complicating factor is the observation of an active suppression of NK-mediated killing by some fungal species (Schmidt et al. 2013a).

\section{Innate-Like Lymphocytes}

Lymphocytes, such as T-helper cells, cytotoxic $\mathrm{T}-$, and B-cells are considered part of the adaptive immune system and will not be discussed here. However, there are cells of lymphoid origin that are considered part of the innate system, as they possess more innate-like qualities than their adaptive relatives. These cells include $\gamma \delta$ $\mathrm{T}$ cells, recently discovered innate lymphoid cells (ILCs), and invariant natural killer (iNK) T cells.

$\gamma \delta \mathrm{T}$ cells are characterized by the expression of an invariant $\mathrm{T}$-cell receptor (TCR), 
made up of the $\gamma$ and $\delta$ chains, and thought to be particularly important in mucosal defenses, as they are found primarily in the gut and make large amounts of IL-17 (Gladiator et al. 2013), a cytokine crucial for antifungal mucosal defenses (see below). Similarly, ILCs are also found primarily in mucosal surfaces and thought to play important roles in fungal allergic asthma (see next section). The contribution of ILCs in fungal infections is a new area with results that are difficult to reconcile currently. The confusing nomenclature of ILCs has also made this difficult and, thus in this work, we will use the grouping system proposed by Spits et al. (2013) in which ILC- 1 are predominantly IFN- $\gamma$ producing, ILC-2 are IL-4 / 13 producing, and ILC-3 are IL-17 producing. Using this system, ILC-3 was shown to potentially play important roles in mucosal candidiasis (Gladiator et al. 2013; see below), whereas ILC-2 were shown to have a detrimental role in $C$. neoformans immunity (Flaczyk et al. 2013), suggesting a dependence on anatomical location and fungal species.

iNK T cells are a rare population of lymphocytes expressing an invariant TCR that recognizes lipid antigens in the major histocompatibility complex (MHC) molecule CD1d. Animals deficient in CD1d, and therefore unable to initiate NK T-cell responses, were recently shown to have an increased susceptibility to A. fumigatus infections (Cohen et al. 2011). The investigators of this article were not able to identify a fungal lipid responsible for the phenotype, instead suggesting the involvement of self lipids. However, another group has recently identified an Aspergillus-derived lipid, termed asperamide B, which could be used to induce airway hyperreactivity and activation of iNK T cells in vivo (Albacker et al. 2013).

\section{ECs}

ECs are the first point of contact with microbes and, although not typically considered immune cells, there have been several recent examples of ECs contributing to the innate immune response, primarily through the production of chemokines, such as IL-8. Vaginal ECs have been shown to produce inflammatory chemo- kines in response to $C$. albicans (Yano et al. 2012), whereas corneal and bronchial ECs both produce inflammatory cytokines in response to A. fumigatus (Guo and Wu 2009; Sun et al. 2012). Mechanisms driving EC chemokine production include the ligation of TLRs (Guo and Wu 2009) and stimulation with antimicrobial peptides (Wagener et al. 2013). ECs are also important in maintaining commensal populations and initiating a proinflammatory response following a switch to a pathogenic phenotype; Moyes and colleagues showed that oral ECs only switched on inflammatory pathways following stimulation with the pathogenic hyphal form of C. albicans and not the commensal yeast form, and that this biphasic response was controlled by mitogen-associated protein or mitogen-activated protein kinase signaling and fungal burden (Moyes et al. 2010). Characterization of PRR expression in ECs has so far been limited to TLR family members, although expression of C-type lectin receptors (CLRs) is less well defined (Weindl et al. 2010). However, it was recently shown that Dectin-1, a critical antifungal PRR (see below), can be induced on human bronchial ECs exposed to A. fumigatus, which was required for the induction of ROS and inflammatory chemokines (Sun et al. 2012).

\section{Innate Immune Regulation in Barrier Tissues}

The skin and mucosal surfaces act as physical barriers between the environment and deep tissues. Many of the cell types described above are found in abundance within barrier tissues and are important in surveillance, maintaining commensal relationships, and protection from invasion. This section will outline the most recent developments in the regulation of antifungal immunity within barrier tissues.

\section{Skin}

Human skin is readily colonized by fungi, predominantly Malassezia species (Findley et al. 2013). Malassezia are pathogenic yeast that are associated with exacerbating various skin diseases, including atopic eczema and atopic dermatitis (AD), in which barrier function and im- 
R.A. Drummond et al.

mune regulation is compromised (Saunders et al. 2012). In these diseases, Malassezia-derived products have been shown to influence host responses, including the generation of cross-reactive $\mathrm{T}$ cells that exacerbated $\mathrm{AD}$ (Balaji et al. 2011), and down-regulation of human DC maturation and proinflammatory cytokine production (Vlachos et al. 2012). Other pathogenic fungi that target the skin include Trichophyton species, which cause common infections of the skin and nails (onychomycosis), and also C. albicans. C. albicans infections of the skin were recently shown to be controlled by different DC subsets resident in the skin, Langerhans cells, and Langerin ${ }^{+}$dermal DCs, which were each responsible for driving Th17 and Th1 adaptive immunity, respectively (Igyarto et al. 2011).

\section{Respiratory Tract}

Inhalation is a common route of exposure to fungal spores in the environment. In immunecompromised patients, these spores may begin to germinate, resulting in lethal invasive infection, such as invasive pulmonary aspergillosis (IPA) and other fungal pneumonias (Table 1). More commonly, the inhalation of fungal spores results in sensitization and exacerbation of allergy and asthma. Allergic bronchopulmonary aspergillosis (ABPA) is a hypersensitivity disorder to A. fumigatus, leading to severe asthma symptoms and affects nearly five million people worldwide (Agarwal et al. 2013; Denning et al. 2013). ABPA pathogenesis is poorly understood, although recent insights have identified some mechanisms that may help future development of therapies. For example, Dectin-1 recognition of $A$. fumigatus was recently shown to enhance immunopathology through IL-22 (Lilly et al. 2012), whereas C3aR ${ }^{-/-}$mice presented with reduced allergic symptoms when sensitized with A. fumigatus chitin (Roy et al. 2013). Other fungi that have been shown to exacerbate asthma are C. neoformans and Alternaria alternata, which induce trademark symptoms of allergy including eosinophilia and Th2 polarization (Goldman et al. 2006; Doherty et al. 2012). Recently, ILC-2 cells have been shown to play major roles in allergic responses to Alternar- ia through the production of IL-5 and IL-13 (Bartemes et al. 2012; Doherty et al. 2012). It is hoped that their further characterization may help identify mechanisms of allergic hyperresponsiveness to fungal allergens and novel therapeutic targets.

\section{Gastrointestinal Tract}

Fungi have been described as both commensals and pathogens in the human gastrointestinal (GI) tract. The most commonly described human fungal commensal is C. albicans, which initiates a distinct commensalism transcriptional program to optimize growth within the GI tract (Pande et al. 2013). However, high levels of colonization have been associated with enhanced severity of ulcerative colitis and Crohn's disease (Kumamoto 2011), and many cases of systemic candidiasis are thought to originate from commensal populations in the gut (Odds et al. 2006; Miranda et al. 2009). It has therefore been recognized that a better understanding of relationships with fungal commensals is important to delineating disease pathogenesis. It has recently been shown that the mammalian intestinal microbiota has diverse fungal species and is in greater abundance than previously appreciated (Iliev et al. 2012). Analysis of the murine fungal microbiome by Iliev and colleagues identified several fungal species belonging to the genera of Candida, Saccharomyces, and Trichosporon (Iliev et al. 2012). These fungi interacted with the innate immune system via the PRRs Dectin-1 (Iliev et al. 2012) and SIGNR3 (Eriksson et al. 2013), and absence of these interactions could enhance severity of a murine model of colitis because of loss of fungal recognition and barrier integrity (Iliev et al. 2012; Eriksson et al. 2013). Similarly, humans with a Dectin-1 genetic polymorphism were found to be associated with more severe forms of colitis, possibly caused by the disturbance of fungal recognition in the GI tract (Iliev et al. 2012). Interestingly, although Dectin-1 has been shown to be essential for the protection against invasive infections of the gut, it does not appear to play a role in the maintenance of commensal fungal populations in the GI tract (Vautier et al. 2012). 


\section{Genital-Urinary Tract}

The most common fungal pathogen colonizing the genital-urinary tract is C. albicans (Jaeger et al. 2013). Vulvovaginal candidiasis (VVC) is thought to affect $75 \%$ of adult woman at least once in their lifetime, and $8 \%$ of these women are estimated to be recurrent sufferers (RVVC) (Jaeger et al. 2013). Interestingly, recurrent infections can occur in women with no other known medical complaints and it is still unclear why vaginal candidiasis occurs more often in some individuals. Recent developments have, however, shed some light on mechanisms conferring enhanced susceptibility to RVVC. Animals deficient in IDO1, an enzyme promoting tolerant T-cell responses and production of tolerogenic kynurenines, were shown to have increased susceptibility to VVC and treatment with kynurenines could alleviate disease (De Luca et al. 2013). S100 alarmin proteins have also been shown to mediate an immunopathogenic response in susceptible patients, which was interestingly independent of Th17 cells that are known for their anti-Candida properties and a role in the induction of S100 alarmins (Yano et al. 2012). The balance between tolerogenic and protective responses appears to be critical, however, as mice deficient in IL-22, a protective inflammatory cytokine, were also more susceptible to VVC (De Luca et al. 2013). Human polymorphisms reflect the delicate nature of this balance; a polymorphism in the IL-4 gene was found in significantly higher frequency in RVVC sufferers compared with healthy controls, which correlated to enhanced levels of anti-inflammatory IL-4 resulting in a reduction in nitric oxide levels and fungal killing (Jaeger et al. 2013).

\section{INNATE RECOGNITION}

The initiation of an immune response begins with the innate recognition of the pathogen by PRRs, which drive early protective mechanisms that are critical to host defense (Fig. 1). There are several families of PRRs that are grouped based on phylogeny, structure, and function. Toll-like receptors (TLRs) and CLRs are the key families involved in antifungal immunity, and we will discuss selected members from these families based on their identified major roles in antifungal responses. Although we discuss PRRs as individual entities, it is important to remember that these PRRs do not work alone and collaborative responses and redundancy are common in mammalian immunology. Indeed, animals and humans lacking signaling adaptors shared by several PRRs tend to show more severe phenotypes than the single PRR deficiencies (Gross et al. 2006; Glocker et al. 2009).

\section{TLRs}

TLRs initiate intracellular signaling pathways using MyD88 or the TRIF adaptor proteins, which ultimately activate transcription factors NF- $\kappa \mathrm{B}$ and the interferon-regulatory factors (O'Neill et al. 2013). TLR-dependent cellular responses that promote antifungal immunity include the production of type I interferons (IFNs) (Bourgeois et al. 2011) and proinflammatory cytokines TNF- $\alpha$ and IL-12 (RamirezOrtiz et al. 2008, 2011), and the promotion of adaptive immunity (Carvalho et al. 2012).

MyD88-deficient mice, which have defective TLR responses from multiple family members, have shown a role for TLRs in immunity to a range of pathogenic fungi including C. albicans (Marr et al. 2003), A. fumigatus (Bretz et al. 2008), and C. neoformans (Biondo et al. 2005). This does not appear to be the case in humans, however. MyD88-deficient humans are highly susceptible to bacterial infections but not fungal (von Bernuth et al. 2008), although associations with systemic candidiasis and TLR-1/4 polymorphisms have been described (Van der Graaf et al. 2006; Plantinga et al. 2012). This is in contrast to patients deficient in the CLR-signaling adaptor, CARD9, who have a high risk of developing severe fungal infections (Glocker et al. 2009). Indeed, one of the primary roles of TLRs in fungal immunity is thought to be modulation of CLR-dependent responses and several examples of TLR/CLR collaboration have been described (Netea et al. 2006). TLR-2, which recognizes fungal glycolipids (Bauer et al. 2008), has a well-documented relationship with Dectin-1 in which synergy promotes phagocytosis and cy- 
R.A. Drummond et al.

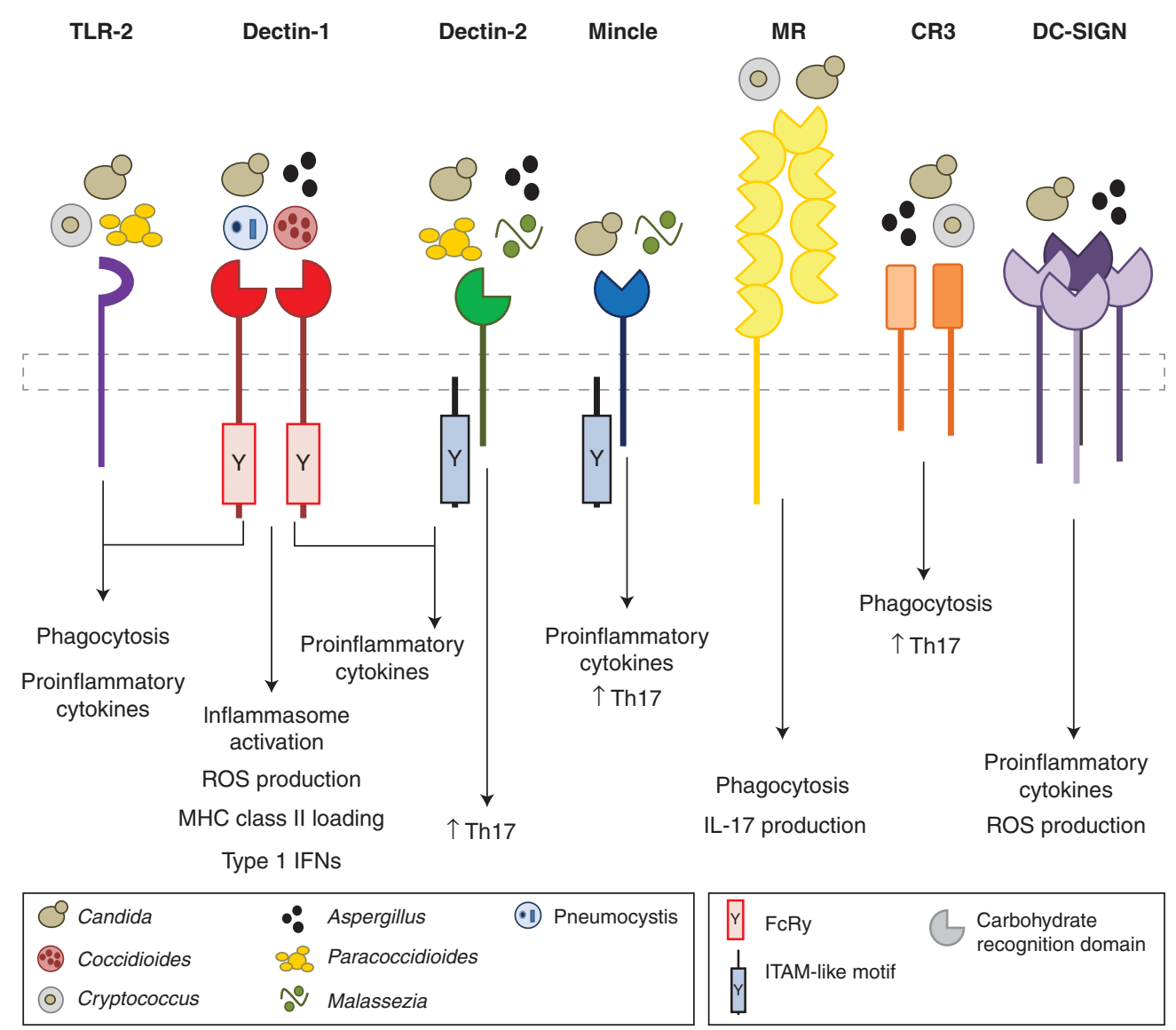

Figure 1. The PRRs discussed herein are depicted showing the fungal species they recognize and downstream effector functions they mediate following recognition. Receptor collaboration between Dectin-1 and TLR-2, and Dectin-1 and Dectin-2, is also indicated by conjoining arrows. See main text for all references.

tokine production (Drummond et al. 2011), and cross-regulation between signaling pathways results in specifically tailored responses (Dennehy et al. 2009). Indeed, the lack of TLR/CLR collaboration can have a profound effect on the outcome of infection. Fonsecaea pedrosoi infections, which cause chromoblastomycosis, could be resolved in vivo through the external application of TLR agonists, which repaired defective TLR recognition, and required cooperative CLR recognition and downstream signaling (Da Glória Sousa et al. 2011).

\section{Dectin-1}

Dectin-1 is the best-described antifungal CLR that recognizes exposed $\beta$-glucans (Brown and
Gordon 2001) in the cell walls of numerous pathogenic fungi, including C. albicans, A. fumigatus, and Pneumocystis carinii (Drummond and Brown 2011). Dectin-1 is expressed primarily by myeloid cells and drives complex intracellular signaling pathways of which the best characterized is the Syk-CARD9 pathway (Drummond et al. 2011; Hardison and Brown 2012). Signaling then leads to a multitude of cellular responses, including phagocytosis, cytokine production, the respiratory burst, and activation of inflammasomes. The intracellular signaling pathways downstream from Dectin-1 have been reviewed extensively elsewhere (Drummond et al. 2011; Hardison and Brown 2012). Briefly, the tyrosine in the immunoreceptor tyrosine-based activation motif-like mo- 
tif (YXXL) is phosphorylated by Src-family kinases on $\beta$-glucan binding. This phosphorylation event allows recruitment of Syk kinase and the formation of a molecular scaffold composed of CARD9, Bcl10, and MALT1. The signaling cascade that follows is responsible for the activation and translocation of several transcription factors into the nucleus (NF-кB, AP1, NFAT), leading to cytokine production and gene transcription.

Innate recognition and the downstream functions of Dectin-1 have significant functional consequences to in vivo antifungal immunity. Dectin-1-deficient mice show accelerated mortality when systemically infected with C. albicans (Taylor et al. 2007) and A. fumigatus (Werner et al. 2009), whereas increased burdens have been reported with P. carinii (Saijo et al. 2007) and Coccidioides immitus (Viriyakosol et al. 2013). The human Dectin-1 polymorphism (Y238X), which renders patients Dectin-1 deficient (Ferwerda et al. 2009), has also been linked to an increased susceptibility to mucosal candidiasis, and an increased risk of invasive aspergillosis following transplant surgery (Cunha et al. 2010; Chai et al. 2011). Other recently identified downstream functions of Dectin-1 include modulation of the autophagy pathway to promote antigen presentation of fungal antigens on MHC Class II (Ma et al. 2012) and production of type I IFNs needed for efficient renal infiltration during murine systemic candidiasis (Del Fresno et al. 2013).

\section{Dectin-2}

Members of the Dectin-2 family have a single carbohydrate recognition domain and lack intracellular tails with signaling motifs, although there are some members that are exceptions (e.g., DCIR) (Kerscher et al. 2013). Dectin-2 is the best-characterized member of this cluster, and has been shown to bind a number of fungal species including C. albicans, P. brasiliensis, A. fumigatus (Kerscher et al. 2013), and Malassezia (Ishikawa et al. 2013). Dectin-2 binds highmannose-containing structures and, accordingly, $\alpha$-mannose and a mannose-rich glycoprotein were recently identified as ligands (Saijo et al.
2010; Ishikawa et al. 2013). Dectin-2 associates with $\mathrm{FcR} \gamma$ to drive intracellular signaling pathways, of which the best characterized is the Syk-CARD9 pathway, shared with Dectin-1 (Drummond et al. 2011; Hardison and Brown 2012). Protective roles for Dectin-2 in antifungal defense have been best characterized for C. albicans, in which Dectin-2-dependent $\mathrm{CD} 4{ }^{+} \mathrm{T}$-cell Th17 polarization (Robinson et al. 2009) was recently shown to contribute to fungal clearance as Dectin- $2^{-/}$animals had reduced survival and greater fungal burdens when systemically challenged (Saijo et al. 2010).

\section{Mincle}

Mincle is another member of the Dectin-2 family and, like Dectin-2, associates with FcR $\gamma$ and signals through Syk-CARD9. Using deficient mouse models, Mincle has been shown to play protective roles during infections with $C$. albicans (Wells et al. 2008) and Malassezia (Yamasaki et al. 2009). The specific ligands that activate Mincle are currently unidentified for $C$. albicans, whereas Malassezia-derived glyceroglycolipid and mannitol-linked fatty acids were recently described to activate Mincle-dependent cytokine production (Ishikawa et al. 2013). Cytokine production appears to be the main protective mechanism downstream from Mincle, as phagocytosis is unaffected in the absence of this PRR (Wells et al. 2008). Other potential roles for Mincle include the modulation of adaptive immunity, which has been described in antimycobacterial responses (Schoenen et al. 2010), although this has yet to be shown during fungal infections.

\section{Mannose Receptor (CD206)}

The mannose receptor (MR) recognizes a broad range of pathogenic microbes including bacteria, parasites, viruses, and fungi through terminally mannosylated molecules (Drummond and Brown 2013). Several antifungal activities downstream from the MR have been shown, including the production of IL-17 from human peripheral blood mononuclear cells (PBMCs) stimulated with $C$. albicans mannans (van de 
R.A. Drummond et al.

Veerdonk et al. 2009), phagocytosis of C. albicans yeast in DCs (Donini et al. 2007), and are also hypothesized to be involved with sampling of phagosomes because of the late-stage recruitment pattern (Heinsbroek et al. 2008). Despite these roles in antifungal immunity, the MR appears to be redundant for a number of fungal infections (Hardison and Brown 2012) except C. neoformans in which $\mathrm{MR}^{-/-}$ mice were shown to be highly susceptible because of defective $\mathrm{CD} 4^{+} \mathrm{T}$-cell responses (Dan et al. 2008).

\section{Complement Receptor 3}

Complement receptor 3 (CR3) is an integrin made up of CD11b and CD18, and is part of the evolutionary ancient complement system that marks and attacks foreign microbes using functionally diverse complement proteins released by a proteolytic cascade (Sandor et al. 2013). CR3 is involved with leukocyte adhesion, phagocytosis, and chemotaxis using mechanisms that can either be dependent or independent on other components of the complement system (van Bruggen et al. 2009). CR3 has been shown to bind $\beta$-glucan-containing particles (van Bruggen et al. 2009) and may act as the primary $\beta$-glucan phagocytic receptor in human neutrophils that, unlike murine neutrophils, were not dependent on Dectin-1 for $\beta$ glucan phagocytosis (van Bruggen et al. 2009). CR3 may also prove to be an important link between the innate and adaptive immune systems through functions independent of $\beta$-glucan recognition. CR3 was shown to help drive Th1 and Th17 responses during A. fumigatus infections (Gresnigt et al. 2013), and has also been described to promote antibody-mediated complement-independent phagocytosis (Taborda and Casadevall 2002).

\section{DC-SIGN}

DC-SIGN is a human CLR expressed on myeloid cells that binds fucose/mannose-containing glycans. There are eight murine homologs (named SIGNR), which have been used to study the probable antifungal activities of DC-SIGN.
In vitro assays have shown SIGNR1 recognition of $C$. albicans leading to cytokine production (Takahara et al. 2012) and activation of the respiratory burst (Takahara et al. 2011), although some of these functions seemed to depend on Dectin-1 signaling, suggesting a collaborative effort (Takahara et al. 2011). The phenotype of SIGNR1-deficient mice following fungal infection has not yet been reported and, therefore, only in vivo roles to bacteria and parasites have been described so far (Lanoue et al. 2004; Saunders et al. 2009). However, it has been shown in a small cohort of patients that polymorphisms in DC-SIGN are associated with developing IPA, although the mechanism remains to be defined (Sainz et al. 2012).

\section{IL-17 DEFENSES}

Immunity to fungal infections is traditionally considered in the purview of adaptive immune responses, particularly because of the incidence of fungal diseases in HIV/acquired immunodeficiency syndrome patients, such as Pneumocystis pneumonia, oral candidiasis, and cryptococcal meningitis (Glocker and Grimbacher 2010). This concept was reinforced by the discovery that the cytokine IL-17 is critical for immunity to fungal infections, particularly mucosal candidiasis (Huppler et al. 2012). Although IL-17 is classically associated with $\mathrm{CD} 4^{+}$Th17 cells, in recent years there has been an increasing appreciation of the importance of innate lymphoid sources of IL-17 (Cua and Tato 2010; Spits et al. 2013; Walker et al. 2013). These sources include NK T cells, $\gamma \delta$ T cells, CD $4{ }^{-} \mathrm{CD} 8^{-} \mathrm{TCR}^{+}$cells, and "natural" Th17 cells that do not require activation by a specific antigen and are therefore considered innate. Nonetheless, these innate "type 17" cells bear several similarities to conventional Th17 cells in that they express CCR6, IL-7R $\alpha$, IL-23R, and the master transcription factor ROR- $\gamma$ t. However, it is thought that they do not necessarily require a TCR for their development as some cell types have been identified in Rag1 ${ }^{-/-}$mice, which do not have an adaptive immune system (Cua and Tato 2010). There is also literature proposing that certain myeloid cells may be additional sources of 
IL-17 (e.g., mast cells, neutrophils, and macrophages) (Hueber et al. 2010; Lin et al. 2011; Werner et al. 2011); however, this remains controversial as many cases can be explained by receptor-mediated uptake of cytokine rather than de novo production. Intestinal Paneth cells were also reported to express IL-17 (Takahashi et al. 2008), which may play a key role in maintaining commensal populations of fungi in the GI tract.

In fungal settings, innate IL-17-producing cells have been most closely examined in the context of mucosal candidiasis in which IL-17 is crucial to defense. Humans with defects at various points along the Th17 pathway are susceptible to mucosal, but usually not disseminated, candidiasis (Hernández-Santos and Gaffen 2012). Although many of these defects are associated with reduced adaptive Th17 responses, innate immunity has also been shown to be compromised. In patients with hyper-IgE/ Job's syndrome, who have mutations in STAT3 resulting in reduced IL-6/23 signaling, a reduction in salivary antimicrobial peptides was found that correlated to reduced antifungal activity of the saliva, and may explain why these patients have increased growth of C. albicans in the oral cavity (Conti et al. 2011). In mice, C. albicans is not a commensal organism (Suegara et al. 1979; Iliev et al. 2012) permitting evaluation of both innate and adaptive responses. The use of mouse models has therefore provided key insights to IL-17 regulation and production in response to C. albicans. For example, in dermal Candida infections, the $\gamma \delta \mathrm{T}$ cell population was shown to be the dominant source of IL-17, which contributed to the resolution of skin lesions (Kagami et al. 2010; Hirota et al. 2011; Igyarto et al. 2011). In oropharyngeal candidiasis (OPC), there is also a powerful innate response as the organism is cleared within 3-4 days of infection without notable involvement in the draining lymph node or induction of adaptive immunity, yet IL-17 is crucial for protection (Kamai et al. 2001; Conti et al. 2009; Hernández-Santos et al. 2013). One report suggests that ILC-3 cells may be the source of protective IL-17 in OPC based on a claim that $\mathrm{Rag1}^{-/-}$mice are resistant to disease (Gladia- tor et al. 2013). However, it was not shown in that report that ILC-3 cells were actually producing IL-17, and Rag1 ${ }^{-/-}$mice have been shown to be very susceptible to OPC in other systems (Pandiyan et al. 2011; Hernández-Santos et al. 2013). In disseminated candidiasis, IL-17 also protects against infection (Huang et al. 2004; Saijo et al. 2010; van de Veerdonk et al. 2010), although it is unclear whether the dominant source is adaptive or innate. However, as most disseminated candidiasis models are studied in a time frame compatible with development of adaptive immunity, indirect evidence suggests that adaptive responses are important.

\section{INFLAMMASOMES}

Inflammasomes are a recently described family of proteins originally characterized for their crucial role in the induction of inflammation, which contain a carboxy-terminal leucine rich repeat, a central nucleotide oligomerization domain, and an amino-terminal effector domain used to categorize inflammasomes into one of three classes: pyrin-containing NOD-like receptors (NLRPs), CARD-containing NOD-like receptors (NLRCs), and a baculovirus inhibitor of apoptosis protein repeat (BIR) domain-containing class. Caspase-1, a proteolytic enzyme, is activated following the formation of inflammasomes and is responsible for processing proIL-1 $\beta$. IL-1 functions both locally and systemically (Roh et al. 1986; Gauldie et al. 1987) and is distinct from many other cytokines as its production and release involves a two-step process. The first step is the transcriptional upregulation of IL-1 $\beta$ as an inactive precursor (pro-IL-1 $\beta$ ) downstream from Dectin-1 and TLR-2/4 (Netea et al. 2002; Bellocchio et al. 2004; Hise et al. 2009), and the second step is a proteolytic cleavage by caspase- 1 releasing active IL-1 $\beta$ (Wilson et al. 1994). Similarly, proIL-18 is also cleaved by caspase-1 (Pedra et al. 2007), although this cytokine does not appear to play as predominant a role in fungal immunity as IL-1.

Host responses to numerous fungal pathogens depend on IL-1 receptor signaling (which 
R.A. Drummond et al.

can be activated by both IL- $1 \alpha$ and IL-1 $\beta$ ), including C. albicans infections (Bellocchio et al. 2004; Hise et al. 2009), Fusarium species causing ocular keratitis (Tarabishy et al. 2012), and Histoplasma capsulatum pulmonary disease (Deepe and McGuinness 2006). Interestingly, the dependence on IL-1R signaling appears to be dependent on both the species and site of infection, as it was not required in pulmonary disease caused by Aspergillus (Bellocchio et al. 2004; Deepe and McGuinness 2006), but essential in Aspergillus-mediated ocular keratitis (Leal et al. 2010).

The best-studied inflammasome to date, NLRP3 (also known as NALP3) was identified as a result of a gain-of-function mutation associated with autoinflammatory diseases characterized by high levels of IL-1 $\beta$ (Aganna et al. 2002; Dowds et al. 2003, 2004; Agostini et al. 2004). NLRP3 is expressed in macrophages, DCs, T cells, B cells, and nonkeratinizing mucosal epithelium (Kummer et al. 2007), and responds to a wide range of stimuli including every class of microorganism (Allen et al. 2009; Craven et al. 2009; Dostert et al. 2009; Harder et al. 2009; Shio et al. 2009; Thomas et al. 2009), and host-derived molecules, such as ATP (Walev et al. 1995; Mariathasan et al. 2006; Petrilli et al. 2007; Qu et al. 2007), uric acid crystals (Martinon et al. 2006), and fibrillar amyloid- $\beta$ (Halle et al. 2008). Crystalline compounds, such as silica crystals, asbestos, and aluminum salts, are also potent activators (Dostert et al. 2008; Hornung et al. 2008).

The first evidence for a role for NLRP3 in antifungal defenses was established using a murine model of oral candidiasis, in which NLRP3 deficiency resulted in increased susceptibility to mucosal candidiasis, as well as subsequent disseminated infections (Hise et al. 2009). NLRP3 has also been shown to be critical for protection in intravenous models of Candida challenge (Gross et al. 2009; Joly et al. 2009). The specific component of Candida required for activation of the NLRP3 inflammasome is not yet known; however, several yeast cell-wall preparations, including curdlan (Kumar et al. 2009), zymosan, and mannan (Lamkanfi et al. 2009), have been shown to activate NLRP3, and a recent report identified secreted aspartic proteases from Candida as capable of stimulating IL- $1 \beta$ release via NLRP3 (Pietrella et al. 2013). Aspergillus hyphal fragments, but not spores, have also been found to invoke the NLRP3 inflammasome to mediate IL- $1 \beta$ release from monocytes (Said-Sadier et al. 2010). Despite extensive research, relatively little is known about the precise molecular events involved in NLRP3 activation. In one study, it was determined that internalization and subsequent lysosomal damage, a characteristic common to crystalline activators, were required for Candida-mediated IL- $1 \beta$ release from macrophages (Joly et al. 2009; Pietrella et al. 2013). However, a conflicting report identified no discernible role for lysosomal damage in response to Candida in DCs (Gross et al. 2009). It remains to be seen whether these differences are attributable to different Candida strains used or point toward differential mechanisms for inflammasome activation in these two cell types. For Aspergillus, it was found that $\mathrm{K}^{+}$efflux and ROS production was required for IL- $1 \beta$ release from immortalized human monocytes (SaidSadier et al. 2010). These mechanisms were also found to be important for human PBMC IL-1 $\beta$ release in response to Candida (Pietrella et al. 2013).

Limited studies have been performed on the role of other inflammasomes in fungal immunity. A noncanonical inflammasome using caspase- 8 was recently shown to be activated directly downstream from Dectin-1 in response to C. albicans, and was independent of phagocytosis (Gringhuis et al. 2012). Another inflammasome, NLRC4 (formerly known as IPAF), has been best studied for its role in inflammatory responses to common bacterial pathogens (Miao et al. 2006; Franchi et al. 2007; Suzuki et al. 2007) and was recently shown to mediate a tissue-specific protective response to C. albicans (Tomalka et al. 2011). Another inflammasome studied in fungal infection is NLRP10, which was found to have minimal impact on the release of IL-1 $\beta$ in response to Candida; however, mortality was increased in $\mathrm{Nlrp} 10^{-/-}$ mice following intravenous challenge because of extensive kidney damage and abrogated Th1 and Th17 T-cell responses (Joly et al. 2012). 


\section{CONCLUDING REMARKS}

This work has provided an overview of the essential players in innate antifungal immunity. Although our understanding has recently expanded significantly in certain areas, such as the identification of fungal ligands, there are many aspects of innate immunity that are yet to be defined and understood. For example, further definition of PRR-signaling pathways and the source of innate IL-17, as outlined here, will be paramount to our understanding of early antifungal responses. Furthermore, much work is needed to clarify how individual PRRs work together in the recognition of different fungal pathogens, and how this influences killing and cell behavior. These insights will ultimately help shape the design of future treatments, particularly antifungal vaccines of which there are currently none available. As more advances in our understanding are made, it is likely we will see better diagnostics and treatments to help reduce the mortality of invasive fungal infections.

\section{ACKNOWLEDGMENTS}

We thank the Wellcome Trust and Medical Research Council (R.A.D. and G.D.B.) for funding support. S.L.G. is supported by National Institutes of Health (NIH) Grant R01-DE022550, and A.G.H. is supported in part by NIH Grant R01-DE018279.

\section{REFERENCES}

Aganna E, Martinon F, Hawkins PN, Ross JB, Swan DC, Booth DR, Lachmann HJ, Bybee A, Gaudet R, Woo P, et al. 2002. Association of mutations in the NALP3/ CIAS1/PYPAF1 gene with a broad phenotype including recurrent fever, cold sensitivity, sensorineural deafness, and AA amyloidosis. Arthritis Rheum 46: 2445-2452.

Agarwal R, Chakrabarti A, Shah A, Gupta D, Meis JF, Guleria R, Moss R, Denning DW, ISHAM ACA. 2013. Allergic bronchopulmonary aspergillosis: Review of literature and proposal of new diagnostic and classification criteria. Clin Exp Allergy 43: 850-873.

Agostini L, Martinon F, Burns K, McDermott MF, Hawkins PN, Tschopp J. 2004. NALP3 forms an IL-1 $\beta$-processing inflammasome with increased activity in Muckle-Wells autoinflammatory disorder. Immunity 20: 319-325.

Albacker LA, Chaudhary V, Chang Y-J, Kim HY, Chuang Y-T, Pichavant M, DeKruyff RH, Savage PB, Umetsu
DT. 2013. Invariant natural killer T cells recognize a fungal glycosphingolipid that can induce airway hyperreactivity. Nat Med 19: 1297-1304.

Allen IC, Scull MA, Moore CB, Holl EK, McElvania-TeKippe E, Taxman DJ, Guthrie EH, Pickles RJ, Ting JP. 2009. The NLRP3 inflammasome mediates in vivo innate immunity to influenza A virus through recognition of viral RNA. Immunity 30: 556-565.

Balaji H, Heratizadeh A, Wichmann K, Niebuhr M, Crameri R, Scheynius A, Werfel T. 2011. Malassezia sympodialis thioredoxin-specific $\mathrm{T}$ cells are highly cross-reactive to human thioredoxin in atopic dermatitis. J Allergy Clin Immunol 128: 92-99.e4.

Bartemes KR, Iijima K, Kobayashi T, Kephart GM, McKenzie AN, Kita H. 2012. IL-33-responsive lineage- CD25 ${ }^{+}$ CD $44^{\text {hi }}$ lymphoid cells mediate innate type 2 immunity and allergic inflammation in the lungs. J Immunol 188: 1503-1513.

Bauer S, Hartmann G, Goodridge HS, Underhill DM. 2008. Fungal recognition by TLR-2 and Dectin-1. In Toll-like receptors (TLRs) and innate immunity (ed. Hofmann F). Springer, Berlin.

Bellocchio S, Montagnoli C, Bozza S, Gaziano R, Rossi G, Mambula SS, Vecchi A, Mantovani A, Levitz SM, Romani L. 2004. The contribution of the Toll-like/IL-1 receptor superfamily to innate and adaptive immunity to fungal pathogens in vivo. J Immunol 172: 3059-3069.

Biondo C, Midiri A, Messina L, Tomasello F, Garufi G, Catania MI, Bombaci M, Beninati C, Teti G, Mancuso G. 2005. MyD88 and TLR-2, but not TLR-4, are required for host defense against Cryptococcus neoformans. Eur J Immunol 35: 870-878.

Bourgeois C, Majer O, Frohner IE, Lesiak-Markowicz I, Hildering KS, Glaser W, Stockinger S, Decker T, Akira S, Muller M, et al. 2011. Conventional dendritic cells mount a type I IFN response against Candida spp. requiring novel phagosomal TLR-7-mediated IFN- $\beta$ signaling. J Immunol 186: 3104-3112.

Bretz C, Gersuk G, Knoblaugh S, Chaudhary N, RandolphHabecker J, Hackman RC, Staab J, Marr KA. 2008 MyD88 signaling contributes to early pulmonary responses to Aspergillus fumigatus. Infect Immun 76: 952 958.

Brown GD, Gordon S. 2001. Immune recognition: A new receptor for $\beta$-glucans. Nature 413: 36-37.

Brown GD, Denning DW, Gow NAR, Levitz SM, Netea MG White TC. 2012. Hidden killers: Human fungal infections. Sci Transl Med 4: 165rv13.

Byrd AS, O’Brien XM, Johnson CM, Lavigne LM, Reichner JS. 2013. An extracellular matrix-based mechanism of rapid neutrophil extracellular trap formation in response to Candida albicans. J Immunol 190: 4136-4148.

Carter RW, Thompson C, Reid DM, Wong SYC, Tough DF 2006. Preferential induction of $\mathrm{CD} 4^{+} \mathrm{T}$ cell responses through in vivo targeting of antigen to dendritic cellassociated C-type lectin-1. J Immunol 177: 2276-2284.

Carvalho A, De Luca A, Bozza S, Cunha C, D’Angelo C, Moretti S, Perruccio K, Iannitti RG, Fallarino F, Pierini A, et al. 2012. TLR-3 essentially promotes protective class I-restricted memory CD $8{ }^{+} \mathrm{T}$-cell responses to Aspergillus fumigatus in hematopoietic transplanted patients. Blood 119: 967-977. 
R.A. Drummond et al.

Chai LYA, de Boer MGJ, van der Velden W, Plantinga TS, van Spriel AB, Jacobs C, Halkes CJM, Vonk AG, Blijlevens NM, van Dissel JT, et al. 2011. The Y238X stop codon polymorphism in the human $\beta$-glucan receptor Dectin- 1 and susceptibility to invasive aspergillosis. J Infect Dis 203: $736-743$.

Cohen NR, Tatituri RVV, Rivera A, Watts GFM, Kim EY, Chiba A, Fuchs BB, Mylonakis E, Besra GS, Levitz SM, et al. 2011. Innate recognition of cell wall $\beta$-glucans drives invariant natural killer $\mathrm{T}$ cell responses against fungi. Cell Host Microbe 10: 437-450.

Conti HR, Shen F, Nayyar N, Stocum E, Sun JN, Lindemann MJ, Ho AW, Hai JH, Yu JJ, Jung JW, et al. 2009. Th17 cells and IL-17 receptor signaling are essential for mucosal host defense against oral candidiasis. J Exp Med 206: 299-311.

Conti HR, Baker O, Freeman AF, Jang WS, Holland SM, Li RA, Edgerton M, Gaffen SL. 2011. New mechanism of oral immunity to mucosal candidiasis in hyper-IgE syndrome. Mucosal Immunol 4: 448-455.

Craven RR, Gao X, Allen IC, Gris D, Bubeck Wardenburg J, McElvania-TeKippe E, Ting JP, Duncan JA. 2009. Staphylococcus aureus $\alpha$-hemolysin activates the NLRP3-inflammasome in human and mouse monocytic cells. PLoS ONE 4: e7446.

Cua DJ, Tato CM. 2010. Innate IL-17-producing cells: The sentinels of the immune system. Nat Rev Immunol 10: 479-489.

Cunha C, Di Ianni M, Bozza S, Giovannini G, Zagarella S, Zelante T, D'Angelo C, Pierini A, Pitzurra L, Falzetti F, et al. 2010. Dectin-1 Y238X polymorphism associates with susceptibility to invasive aspergillosis in hematopoietic transplantation through impairment of both recipient- and donor-dependent mechanisms of antifungal immunity. Blood 116: 5394-5402.

Da Glória Sousa M, Reid DM, Schweighoffer E, Tybulewicz V, Ruland J, Langhorne J, Yamasaki S, Taylor PR, Almeida SR, Brown GD. 2011. Restoration of pattern recognition receptor costimulation to treat chromoblastomycosis, a chronic fungal infection of the skin. Cell Host Microbe 9: 436-443.

Dan JM, Kelly RM, Lee CK, Levitz SM. 2008. Role of the mannose receptor in a murine model of Cryptococcus neoformans infection. Infect Immun 76: 2362-2367.

Deepe GS Jr, McGuinness M. 2006. Interleukin-1 and host control of pulmonary histoplasmosis. J Infect Dis 194: 855-864.

Del Fresno C, Soulat D, Roth S, Blazek K, Udalova I, Sancho D, Ruland J, Ardavin C. 2013. Interferon- $\beta$ production via Dectin-1-Syk-IRF5 signaling in dendritic cells is crucial for immunity to C. albicans. Immunity 38: 1176-1186.

De Luca A, Iannitti RG, Bozza S, Beau R, Casagrande A, D’Angelo C, Moretti S, Cunha C, Giovannini G, MassiBenedetti C, et al. 2012. CD4 ${ }^{+} \mathrm{T}$ cell vaccination overcomes defective cross-presentation of fungal antigens in a mouse model of chronic granulomatous disease. J Clin Invest 122: 1816-1831.

De Luca A, Carvalho A, Cunha C, Iannitti RG, Pitzurra L, Giovannini G, Mencacci A, Bartolommei L, Moretti S, Massi-Benedetti C, et al. 2013. IL-22 and IDO1 affect immunity and tolerance to murine and human vaginal candidiasis. Plos Pathog 9: e1003486-e1003486.

Dennehy KM, Willment JA, Williams DL, Brown GD. 2009. Reciprocal regulation of IL-23 and IL-12 following coactivation of Dectin-1 and TLR signaling pathways. Eur J Immunol 39: 1379-1386.

Denning DW, Pleuvry A, Cole DC. 2013. Global burden of allergic bronchopulmonary aspergillosis with asthma and its complication chronic pulmonary aspergillosis in adults. Med Mycol 51: 361-370.

Doherty TA, Khorram N, Chang JE, Kim HK, Rosenthal P, Croft M, Broide DH. 2012. STAT6 regulates natural helper cell proliferation during lung inflammation initiated by Alternaria. Am J Physiol-Lung Cell Mol Physiol 303: L577-L588.

Donini M, Zenaro E, Tamassia N, Dusi S. 2007. NADPH oxidase of human dendritic cells: Role in Candida albicans killing and regulation by interferons, Dectin-1 and CD206. Eur J Immunol 37: 1194-1203.

Dostert C, Petrilli V, Van Bruggen R, Steele C, Mossman BT, Tschopp J. 2008. Innate immune activation through Nalp3 inflammasome sensing of asbestos and silica. Science 320: 674-677.

Dostert C, Guarda G, Romero JF, Menu P, Gross O, Tardivel A, Suva ML, Stehle JC, Kopf M, Stamenkovic I, et al. 2009. Malarial hemozoin is a Nalp3 inflammasome activating danger signal. PLoS ONE 4: e6510.

Dowds TA, Masumoto J, Chen FF, Ogura Y, Inohara N, Nunez G. 2003. Regulation of cryopyrin/Pypafl signaling by pyrin, the familial Mediterranean fever gene product. Biochem Biophys Res Commun 302: 575-580.

Dowds TA, Masumoto J, Zhu L, Inohara N, Nunez G. 2004. Cryopyrin-induced interleukin $1 \beta$ secretion in monocytic cells: Enhanced activity of disease-associated mutants and requirement for ASC. J Biol Chem 279: 2192421928.

Drummond RA, Brown GD. 2011. The role of Dectin-1 in the host defence against fungal infections. Curr Opin Microbiol 14: 392-399.

Drummond RA, Brown GD. 2013. Signalling C-type lectins in antimicrobial immunity. Plos Pathog 9: e1003417.

Drummond RA, Saijo S, Iwakura Y, Brown GD. 2011. The role of Syk/CARD9 coupled C-type lectins in antifungal immunity. Eur J Immunol 41: 276-281.

Eriksson M, Johannssen T, von Smolinski D, Gruber AD, Seeberger PH, Lepenies B. 2013. The C-type lectin receptor SIGNR3 binds to fungi present in commensal microbiota and influences immune regulation in experimental colitis. Front Immunol 4: 196.

Feriotti C, Loures FV, de Araujo EF, da Costa TA, Calich VLG. 2013. Mannosyl-recognizing receptors induce an M1-like phenotype in macrophages of susceptible mice but an M2-like phenotype in mice resistant to a fungal infection. PLoS ONE 8: e54845.

Ferwerda B, Ferwerda G, Plantinga TS, Willment JA, van Spriel AB, Venselaar H, Elbers CC, Johnson MD, Cambi A, Huysamen C, et al. 2009. Human Dectin-1 deficiency and mucocutaneous fungal infections. N Eng J Med 361: $1760-1767$.

Findley K, Oh J, Yang J, Conlan S, Deming C, Meyer JA, Schoenfeld D, Nomicos E, Park M, NIH Intramural Se- 
quencing Center Comparative Sequencing Program, et al. 2013. Topographic diversity of fungal and bacterial communities in human skin. Nature 498: 367-370.

Flaczyk A, Duerr CU, Shourian M, Lafferty EI, Fritz JH, Qureshi ST. 2013. IL-33 signaling regulates innate and adaptive immunity to Cryptococcus neoformans. J Immunol 191: 2503-2513.

Franchi L, Kanneganti TD, Dubyak GR, Nunez G. 2007. Differential requirement of P2X7 receptor and intracellular $\mathrm{K}^{+}$for caspase-1 activation induced by intracellular and extracellular bacteria. J Biol Chem 282: 1881018818.

Gauldie J, Sauder DN, McAdam KP, Dinarello CA. 1987. Purified interleukin-1 (IL-1) from human monocytes stimulates acute-phase protein synthesis by rodent hepatocytes in vitro. Immunology 60: 203-207.

Gladiator A, Wangler N, Trautwein-Weidner K, LeibundGutLandmann S. 2013. Cutting edge: IL-17-secreting innate lymphoid cells are essential for host defense against fungal infection. J Immunol 190: 521-525.

Glocker E, Grimbacher B. 2010. Chronic mucocutaneous candidiasis and congenital susceptibility to Candida. Curr Opin Allergy Clin Immunol 10: 542-550.

Glocker EO, Hennigs A, Nabavi M, Schaffer AA, Woellner C, Salzer U, Pfeifer D, Veelken H, Warnatz K, Tahami F, et al. 2009. A homozygous CARD9 mutation in a family with susceptibility to fungal infections. $N$ Eng $J$ Med 361: 1727-1735.

Goldman DL, Davis J, Bommarito F, Shao X, Casadevall A. 2006. Enhanced allergic inflammation and airway responsiveness in rats with chronic Cryptococcus neoformans infection: Potential role for fungal pulmonary infection in the pathogenesis of asthma. J Infect Dis 193 $1178-1186$.

Gresnigt MS, Becker KL, Smeekens SP, Jacobs CWM, Joosten LAB, van der Meer JWM, Netea MG, van de Veerdonk FL. 2013. Aspergillus fumigatus-induced IL-22 is not restricted to a specific Th cell subset and is dependent on complement receptor 3. J Immunol 190: 5629-5639.

Gringhuis SI, Kaptein TM, Wevers BA, Theelen B, van der Vlist M, Boekhout T, Geijtenbeek TBH. 2012. Dectin-1 is an extracellular pathogen sensor for the induction and processing of IL- $1 \beta$ via a noncanonical caspase- 8 inflammasome. Nat Immunol 13: 246-254.

Gross O, Gewies A, Finger K, Schafer M, Sparwasser T, Peschel C, Forster I, Ruland J. 2006. Card9 controls a non-TLR signalling pathway for innate anti-fungal immunity. Nature 442: 651-656.

Gross O, Poeck H, Bscheider M, Dostert C, Hannesschlager N, Endres S, Hartmann G, Tardivel A, Schweighoffer E, Tybulewicz V, et al. 2009. Syk kinase signalling couples to the Nlrp3 inflammasome for anti-fungal host defence. Nature 459: 433-436.

Guo H, Wu XY. 2009. Innate responses of corneal epithelial cells against Aspergillus fumigatus challenge. FEMS Immunol Med Microbiol 56: 88-93.

Halle A, Hornung V, Petzold GC, Stewart CR, Monks BG, Reinheckel T, Fitzgerald KA, Latz E, Moore KJ, Golenbock DT. 2008. The NALP3 inflammasome is involved in the innate immune response to amyloid- $\beta$. Nat Immunol 9: $857-865$.
Harder J, Franchi L, Munoz-Planillo R, Park JH, Reimer T, Nunez G. 2009. Activation of the Nlrp3 inflammasome by Streptococcus pyogenes requires streptolysin $\mathrm{O}$ and NF- $\kappa B$ activation but proceeds independently of TLR signaling and P2X7 receptor. J Immunol 183: 5823-5829.

Hardison SE, Brown GD. 2012. C-type lectin receptors orchestrate antifungal immunity. Nat Immunol 13: 817822.

Hardison SE, Herrera G, Young ML, Hole CR, Wozniak KL, Wormley FL. 2012. Protective immunity against pulmonary Cryptococcosis is associated with STAT1-mediated classical macrophage activation. J Immunol 189: 40604068.

Heinsbroek SEM, Taylor PR, Martinez FO, Martinez-Pomares L, Brown GD, Gordon S. 2008. Stage-specific sampling by pattern recognition receptors during Candida albicans Phagocytosis. PLoS Pathog 4: e1000218.

Hernández-Santos N, Gaffen SL. 2012. Th17 cells in immunity to Candida albicans. Cell Host Microbe 11: 425-435.

Hernández-Santos N, Huppler AR, Peterson AC, Khader SA, McKenna KC, Gaffen SL. 2013. Th17 cells confer long-term adaptive immunity to oral mucosal Candida albicans infections. Mucosal Immunol 6: 900-910.

Hirota K, Duarte JH, Veldhoen M, Hornsby E, Li Y, Cua DJ, Ahlfors H, Wilhelm C, Tolaini M, Menzel U, et al. 2011. Fate mapping of IL-17-producing T cells in inflammatory responses. Nat Immunol 12: 255-263.

Hise AG, Tomalka J, Ganesan S, Patel K, Hall BA, Brown GD, Fitzgerald KA. 2009. An essential role for the NLRP3 inflammasome in host defense against the human fungal pathogen Candida albicans. Cell Host Microbe 5: 487497.

Hornung V, Bauernfeind F, Halle A, Samstad EO, Kono H, Rock KL, Fitzgerald KA, Latz E. 2008. Silica crystals and aluminum salts activate the NALP3 inflammasome through phagosomal destabilization. Nat Immunol 9: 847-856.

Huang WT, Na L, Fidel PL, Schwarzenberger P. 2004. Requirement of interleukin-17A for systemic anti-Candida albicans host defense in mice. J Infect Dis 190: 624-631.

Hueber AJ, Asquith DL, Miller AM, Reilly J, Kerr S, Leipe J, Melendez AJ, McInnes IB. 2010. Cutting edge: Mast cells express IL-17A in rheumatoid arthritis synovium. J Immunol 184: 3336-3340.

Huppler AR, Bishu S, Gaffen SL. 2012. Mucocutaneous candidiasis: The IL-17 pathway and implications for targeted immunotherapy. Arthritis Res Ther 14: 217.

Huston SM, Li SS, Stack D, Timm-McCann M, Jones GJ, Islam A, Berenger BM, Xiang RF, Colarusso P, Mody CH. 2013. Cryptococcus gattii is killed by dendritic cells, but evades adaptive immunity by failing to induce dendritic cell maturation. J Immunol 191: 249-261.

Igyarto BZ, Haley K, Ortner D, Bobr A, Gerami-Nejad M, Edelson BT, Zurawski SM, Malissen B, Zurawski G, Berman J, et al. 2011. Skin-resident murine dendritic cell subsets promote distinct and opposing antigen-specific T helper cell responses. Immunity 35: 260-272.

Iliev ID, Funari VA, Taylor KD, Quoclinh N, Reyes CN, Strom SP, Brown J, Becker CA, Fleshner PR, Dubinsky $\mathrm{M}$, et al. 2012. Interactions between commensal fungi and the C-type lectin receptor Dectin-1 influence colitis. Science 336: 1314-1317. 
R.A. Drummond et al.

Ishikawa T, Itoh F, Yoshida S, Saijo S, Matsuzawa T, Gonoi T, Saito T, Okawa Y, Shibata N, Miyamoto T, et al. 2013. Identification of distinct ligands for the C-type lectin receptors Mincle and Dectin-2 in the pathogenic fungus Malassezia. Cell Host Microbe 13: 477-488.

Islam A, Li SS, Oykhman P, Timm-McCann M, Huston SM, Stack D, Xiang RF, Kelly MM, Mody CH. 2013. An acidic microenvironment increases NK cell killing of Cryptococcus neoformans and Cryptococcus gattii by enhancing perforin degranulation. Plos Pathog 9: e1003439.

Jaeger M, Plantinga TS, Joosten LAB, Kullberg B-J, Netea MG. 2013. Genetic basis for recurrent vulvo-vaginal candidiasis. Curr Infect Dis Rep 15: 136-142.

Joly S, Ma N, Sadler JJ, Soll DR, Cassel SL, Sutterwala FS. 2009. Cutting edge: Candida albicans hyphae formation triggers activation of the Nlrp3 inflammasome. J Immunol 183: 3578-3581.

Joly S, Eisenbarth SC, Olivier AK, Williams A, Kaplan DH, Cassel SL, Flavell RA, Sutterwala FS. 2012. Cutting edge: Nlrp10 is essential for protective antifungal adaptive immunity against Candida albicans. J Immunol 189: 4713 4717.

Kagami S, Rizzo HL, Kurtz SE, Miller LS, Blauvelt A. 2010. IL-23 and IL-17A, but not IL-12 and IL-22, are required for optimal skin host defense against Candida albicans. J Immunol 185: 5453-5462.

Kamai Y, Kubota M, Hosokawa T, Fukuoka T, Filler SG. 2001. New model of oropharyngeal candidiasis in mice. Antimicrob Agents Chemother 45: 3195-3197.

Kelly MN, Zheng MQ, Ruan SB, Kolls J, D'Souza A, Shellito JE. 2013. Memory $\mathrm{CD}^{+}{ }^{+} \mathrm{T}$ cells are required for optimal NK cell effector functions against the opportunistic fungal pathogen Pneumocystis murina. J Immunol 190: 285295.

Kerscher B, Willment JA, Brown GD. 2013. The Dectin-2 family of C-type lectin-like receptors: An update. Int Immunol 25: 271-277.

Kiflmariam MG, Yang HJ, Zhang ZY. 2013. Gene delivery to dendritic cells by orally administered recombinant Saccharomyces cerevisiae in mice. Vaccine 31: 1360-1363.

Kumamoto CA. 2011. Inflammation and gastrointestinal Candida colonization. Curr Opin Microbiol 14: 386-391.

Kumar H, Kumagai Y, Tsuchida T, Koenig PA, Satoh T, Guo Z, Jang MH, Saitoh T, Akira S, Kawai T. 2009. Involvement of the NLRP3 inflammasome in innate and humoral adaptive immune responses to fungal $\beta$-glucan. J Immunol 183: 8061-8067.

Kummer JA, Broekhuizen R, Everett H, Agostini L, Kuijk L, Martinon F, van Bruggen R, Tschopp J. 2007. Inflammasome components NALP 1 and 3 show distinct but separate expression profiles in human tissues suggesting a site-specific role in the inflammatory response. J Histochem Cytochem 55: 443-452.

Lamkanfi M, Malireddi RKS, Kanneganti TD. 2009. Fungal zymosan and mannan activate the cryopyrin inflammasome. J Biol Chem 284: 20574-20581.

Lanoue A, Chatworthy MR, Smith P, Green S, Townsend MJ, Johlin HE, Smith KGC, Fallon PG, McKenzie ANJ. 2004. SIGN-R1 contributes to protection against lethal pneumococcal infection in mice. J Exp Med 200: 1383-1393.
Leal SM Jr, Cowden S, Hsia YC, Ghannoum MA, Momany M, Pearlman E. 2010. Distinct roles for Dectin-1 and TLR-4 in the pathogenesis of Aspergillus fumigatus keratitis. PLoS Pathog 6: e1000976.

Lilly LM, Gessner MA, Dunaway CW, Metz AE, Schwiebert L, Weaver CT, Brown GD, Steele C. 2012. The $\beta$-glucan receptor Dectin-1 promotes lung immunopathology during fungal allergy via IL-22. J Immunol 189: $3653-$ 3660 .

Lin AM, Rubin CJ, Khandpur R, Wang JY, Riblett M, Yalavarthi S, Villanueva EC, Shah P, Kaplan MJ, Bruce AT. 2011. Mast cells and neutrophils release IL-17 through extracellular trap formation in psoriasis. J Immunol 187: 490-500.

Lionakis MS, Fischer BG, Lim JK, Swamydas M, Wan W, Richard Lee C-C, Cohen JI, Scheinberg P, Gao J-L, Murphy PM. 2012. Chemokine receptor Ccr1 drives neutrophil-mediated kidney immunopathology and mortality in invasive Candidiasis. PLoS Pathog 8: e1002865.

Lipinski T, Fitieh A, St Pierre J, Ostergaard HL, Bundle DR, Touret N. 2013. Enhanced immunogenicity of a tricomponent mannan tetanus toxoid conjugate vaccine targeted to dendritic cells via Dectin-1 by incorporating $\beta$ glucan. J Immunol 190: 4116-4128.

Longhi LNA, da Silva RM, Fornazim RC, Spago MC, de Oliveira RTD, Nowill AE, Blotta M, Mamoni RL. 2012. Phenotypic and functional characterization of NK cells in human immune response against the dimorphic fungus Paracoccidioides brasiliensis. J Immunol 189: 935-945.

Loures FV, Pina A, Felonato M, Feriotti C, de Araujo EF, Calich VLG. 2011. MyD88 signaling is required for efficient innate and adaptive immune responses to Paracoccidioides brasiliensis infection. Infect Immun 79: 2470 2480.

Ma J, Becker C, Lowell CA, Underhill DM. 2012. Dectin-1triggered recruitment of light Chain 3 protein to phagosomes facilitates major histocompatibility complex class II presentation of fungal-derived antigens. J Biol Chem 287: 34149-34156.

Mariathasan S, Weiss DS, Newton K, McBride J, O'Rourke K, Roose-Girma M, Lee WP, Weinrauch Y, Monack DM, Dixit VM. 2006. Cryopyrin activates the inflammasome in response to toxins and ATP. Nature 440: 228-232.

Marr KA, Balajee SA, Hawn TR, Ozinsky A, Pham U, Akira S, Aderem A, Liles WC. 2003. Differential role of MyD88 in macrophage-mediated responses to opportunistic fungal pathogens. Infect Immun 71: 5280-5286.

Martinon F, Petrilli V, Mayor A, Tardivel A, Tschopp J. 2006. Gout-associated uric acid crystals activate the NALP3 inflammasome. Nature 440: 237-241.

McCormick A, Heesemann L, Wagener J, Marcos V, Hartl D, Loeffler J, Heesemann J, Ebel F. 2010. NETs formed by human neutrophils inhibit growth of the pathogenic mold Aspergillus fumigatus. Microbes Infect 12: 928-936.

Mednick AJ, Feldmesser M, Rivera J, Casadevall A. 2003. Neutropenia alters lung cytokine production in mice and reduces their susceptibility to pulmonary cryptococcosis. Eur J Immunol 33: 1744-1753.

Miao EA, Alpuche-Aranda CM, Dors M, Clark AE, Bader MW, Miller SI, Aderem A. 2006. Cytoplasmic flagellin activates caspase- 1 and secretion of interleukin $1 \beta$ via Ipaf. Nat Immunol 7: 569-575. 
Miranda LN, van der Heijden IM, Costa SF, Sousa API, Sienra RA, Gobara S, Santos CR, Lobo RD, Pessoa VP, Levin AS. 2009. Candida colonisation as a source for candidaemia. J Hosp Infect 72: 9-16.

Mosser DM, Edwards JP. 2008. Exploring the full spectrum of macrophage activation. Nat Rev Immunol 8: 958-969.

Moyes DL, Runglall M, Murciano C, Shen C, Nayar D, Thavaraj S, Kohli A, Islam A, Mora-Montes H, Challacombe SJ, et al. 2010. A biphasic innate immune MAPK response discriminates between the yeast and hyphal forms of Candida albicans in epithelial cells. Cell Host Microbe 8: 225-235.

Netea MG. 2013. Training innate immunity: The changing concept of immunological memory in innate host defence. Eur J Clin Invest 43: 881-884.

Netea MG, Van Der Graaf CA, Vonk AG, Verschueren I, Van Der Meer JW, Kullberg BJ. 2002. The role of toll-like receptor (TLR)-2 and TLR-4 in the host defense against disseminated candidiasis. J Infect Dis 185: 1483-1489.

Netea MG, Gow NAR, Munro CA, Bates S, Collins C, Ferwerda G, Hobson RP, Bertram G, Hughes HB, Jansen T, et al. 2006. Immune sensing of Candida albicans requires cooperative recognition of mannans and glucans by lectin and Toll-like receptors. J Clin Invest 116: 1642-1650.

Netea MG, Quintin J, van der Meer JWM. 2011. Trained immunity: A memory for innate host defense. Cell Host Microbe 9: 355-361.

Odds FC, Davidson AD, Jacobsen MD, Tavanti A, Whyte JA, Kibbler CC, Ellis DH, Maiden MCJ, Shaw DJ, Gow NAR. 2006. Candida albicans strain maintenance, replacement, and microvariation demonstrated by multilocus sequence typing. J Clin Microbiol 44: 3647-3658.

O’Neill LAJ, Golenbock D, Bowie AG. 2013. The history of Toll-like receptors-Redefining innate immunity. Nat Rev Immunol 13: 453-460.

Pande K, Chen C, Noble SM. 2013. Passage through the mammalian gut triggers a phenotypic switch that promotes Candida albicans commensalism. Nat Genet 45: $1088-1091$.

Pandiyan P, Conti HR, Zheng L, Peterson AC, Mathern DR, Hernández-Santos N, Edgerton M, Gaffen SL, Lenardo MJ. 2011. CD $4^{+} \mathrm{CD}_{2} 5^{+}$Foxp $^{+}$regulatory T cells promote Th17 cells in vitro and enhance host resistance in mouse Candida albicans Th17 cell infection model. Immunity 34: 422-434.

Pedra JH, Sutterwala FS, Sukumaran B, Ogura Y, Qian F, Montgomery RR, Flavell RA, Fikrig E. 2007. ASC/PYCARD and caspase- 1 regulate the IL-18/IFN- $\gamma$ axis during Anaplasma phagocytophilum infection. J Immunol 179: 4783-4791.

Petrilli V, Papin S, Dostert C, Mayor A, Martinon F, Tschopp J. 2007. Activation of the NALP3 inflammasome is triggered by low intracellular potassium concentration. Cell Death Differ 14: 1583-1589.

Pietrella D, Pandey N, Gabrielli E, Pericolini E, Perito S, Kasper L, Bistoni F, Cassone A, Hube B, Vecchiarelli A. 2013. Secreted aspartic proteases of Candida albicans activate the NLRP3 inflammasome. Eur J Immunol 43. 679-692.

Pina A, de Araujo EF, Felonato M, Loures FV, Feriotti C, Bernardino S, Barbuto JAM, Calich VLG. 2013. Myeloid dendritic cells (DCs) of mice susceptible to Paracocci- dioidomycosis suppress $\mathrm{T}$ cell responses whereas myeloid and plasmacytoid DCs from resistant mice induce effector and regulatory T cells. Infect Immun 81: 1064-1077.

Plantinga TS, Johnson MD, Scott WK, van de Vosse E, Edwards DRV, Smith PB, Alexander BD, Yang JC, Kremer D, Laird GM, et al. 2012. Toll-like receptor 1 polymorphisms increase susceptibility to Candidemia. J Infect Dis 205: 934-943.

Qu Y, Franchi L, Nunez G, Dubyak GR. 2007. Nonclassical IL-1 $\beta$ secretion stimulated by P2X7 receptors is dependent on inflammasome activation and correlated with exosome release in murine macrophages. I Immunol 179: $1913-1925$.

Quintin J, Saeed S, Martens JHA, Giamarellos-Bourboulis EJ, Ifrim DC, Logie C, Jacobs L, Jansen T, Kullberg BJ Wijmenga C, et al. 2012. Candida albicans infection affords protection against reinfection via functional reprogramming of monocytes. Cell Host Microbe 12: 223-232.

Ramirez-Ortiz ZG, Specht CA, Wang JP, Lee CK, Bartholomeu DC, Gazzinelli RT, Levitz SA. 2008. Toll-like receptor 9-dependent immune activation by unmethylated CpG motifs in Aspergillus fumigatus DNA. Infect Immun 76: 2123-2129.

Ramirez-Ortiz ZG, Lee CK, Wang JP, Boon L, Specht CA, Levitz SM. 2011. A nonredundant role for plasmacytoid dendritic cells in host defense against the human fungal pathogen Aspergillus fumigatus. Cell Host Microbe 9: 415-424.

Rivera A, Hohl TM, Collins N, Leiner I, Gallegos A, Saijo S, Coward JW, Iwakura Y, Pamer EG. 2011. Dectin-1 diversifies Aspergillus fumigatus-specific $\mathrm{T}$ cell responses by inhibiting T helper type $1 \mathrm{CD} 4 \mathrm{~T}$ cell differentiation. $J$ Exp Med 208: 369-381.

Robinson MJ, Osorio F, Rosas M, Freitas RP, Schweighoffer E, Gross O, SjefVerbeek J, Ruland J, Tybulewicz V, Brown GD, et al. 2009. Dectin-2 is a Syk-coupled pattern recognition receptor crucial for Th17 responses to fungal infection. J Exp Med 206: 2037-2051.

Roh MS, Moldawer LL, Ekman LG, Dinarello CA, Bistrian BR, Jeevanandam M, Brennan MF. 1986. Stimulatory effect of interleukin-1 upon hepatic metabolism. Metabolism 35: 419-424.

Roy RM, Paes HC, Nanjappa SG, Sorkness R, Gasper D, Sterkel A, Wuthrich M, Klein BS. 2013. Complement component 3C3 and C3a receptor are required in chitin-dependent allergic sensitization to Aspergillus fumigatus but dispensable in chitin-induced innate allergic inflammation. MBio 4: e00162-13.

Said-Sadier N, Padilla E, Langsley G, Ojcius DM. 2010. Aspergillus fumigatus stimulates the NLRP3 inflammasome through a pathway requiring ROS production and the Syk tyrosine kinase. PLoS ONE 5: e10008.

Saijo S, Fujikado N, Furuta T, Chung SH, Kotaki H, Seki K, Sudo K, Akira S, Adachi Y, Ohno N, et al. 2007. Dectin-1 is required for host defense against Pneumocystis carinii but not against Candida albicans. Nat Immunol 8: 39-46.

Saijo S, Ikeda S, Yamabe K, Kakuta S, Ishigame H, Akitsu A, Fujikado N, Kusaka T, Kubo S, Chung S-h, et al. 2010. Dectin-2 recognition of $\alpha$-mannans and induction of Th17 cell differentiation is essential for host defense against Candida albicans. Immunity 32: 681-691. 
R.A. Drummond et al.

Sainz J, Lupianez CB, Segura-Catena J, Vazquez L, Rios R, Oyonarte S, Hemminki K, Forsti A, Jurado M. 2012. Dectin-1 and DC-SIGN polymorphisms associated with invasive pulmonary Aspergillosis infection. PLoS ONE 7: e32273.

Sandor N, Kristof K, Parej K, Pap D, Erdei A, Bajtay Z. 2013. CR3 is the dominant phagocytotic complement receptor on human dendritic cells. Immunobiology 218: 652-663.

Saunders SP, Walsh CM, Barlow JL, Mangan NE, Taylor PR, McKenzie ANJ, Smith P, Fallon PG. 2009. The C-type lectin SIGNR1 binds Schistosoma mansoni antigens in vitro, but SIGNR1-deficient mice have normal responses during schistosome infection. Infect Immun 77: 399 404.

Saunders CW, Scheynius A, Heitman J. 2012. Malassezia fungi are specialized to live on skin and associated with dandruff, eczema, and other skin diseases. Plos Pathog 8: e1002701.

Schmidt S, Tramsen L, Perkhofer S, Lass-Florl C, Hanisch M, Roger F, Klingebiel T, Koehl U, Lehrnbecher T. 2013a. Rhizopus oryzae hyphae are damaged by human natural killer (NK) cells, but suppress NK cell mediated immunity. Immunobiology 218: 939-944.

Schmidt S, Zimmermann SY, Tramsen L, Koehl U, Lehrnbecher T. 2013b. Natural killer cells and antifungal host response. Clin Vaccine Immunol 20: 452-458.

Schoenen H, Bodendorfer B, Hitchens K, Manzanero S, Werninghaus K, Nimmerjahn F, Agger EM, Stenger S, Andersen P, Ruland J, et al. 2010. Cutting edge: Mincle is essential for recognition and adjuvanticity of the mycobacterial cord factor and its synthetic analog trehalosedibehenate. J Immunol 184: 2756-2760.

Shio MT, Eisenbarth SC, Savaria M, Vinet AF, Bellemare MJ, Harder KW, Sutterwala FS, Bohle DS, Descoteaux A, Flavell RA, et al. 2009. Malarial hemozoin activates the NLRP3 inflammasome through Lyn and Syk kinases. PLoS Pathog 5: e1000559.

Spits H, Artis D, Colonna M, Diefenbach A, Di Santo JP, Eberl G, Koyasu S, Locksley RM, McKenzie ANJ, Mebius $\mathrm{RE}$, et al. 2013. Innate lymphoid cells-A proposal for uniform nomenclature. Nat Rev Immunol 13: 145-149.

Suegara N, Siegel JE, Savage DC. 1979. Ecological determinants in microbial colonization of the murine gastrointestinal tract-Adherence of Torulopsis pintolopesii to epithelial surfaces. Infect Immun 25: 139-145.

Sun WK, Lu X, Li X, Sun QY, Su X, Song Y, Sun HM, Shi Y. 2012. Dectin-1 is inducible and plays a crucial role in Aspergillus-induced innate immune responses in human bronchial epithelial cells. Eur J Clin Microbiol Infect Dis 31: 2755-2764.

Suzuki T, Franchi L, Toma C, Ashida H, Ogawa M, Yoshikawa Y, Mimuro H, Inohara N, Sasakawa C, Nunez G. 2007. Differential regulation of caspase- 1 activation, pyroptosis, and autophagy via Ipaf and ASC in Shigellainfected macrophages. PLoS Pathog 3: el11.

Taborda CP, Casadevall A. 2002. CR3 (CD11b/CD18) and CR4 (CD11c/CD18) are involved in complement-independent antibody-mediated phagocytosis of Cryptococcus neoformans. Immunity 16: 791-802.

Takahara K, Tokieda S, Nagaoka K, Takeda T, Kimura Y, Inaba K. 2011. C-type lectin SIGNR1 enhances cellular oxidative burst response against C. albicans in cooperation with Dectin-1. Eur J Immunol 41: 1435-1444.

Takahara K, Arita T, Tokieda S, Shibata N, Okawa Y, Tateno H, Hirabayashi J, Inaba K. 2012. Difference in fine specificity to polysaccharides of Candida albicans mannoprotein between mouse SIGNR1 and human DC-SIGN. Infect Immun 80: 1699-1706.

Takahashi N, Vanlaere I, de Rycke R, Cauwels A, Joosten LAB, Lubberts E, van den Berg WB, Libert C. 2008. IL17 produced by Paneth cells drives TNF-induced shock. J Exp Med 205: 1755-1761.

Tarabishy AB, Hise AG, Traboulsi EI. 2012. Ocular manifestations of the autoinflammatory syndromes. Ophthalmic Genet 33: 179-186.

Taylor PR, Tsoni SV, Willment JA, Dennehy KM, Rosas M, Findon H, Haynes K, Steele C, Botto M, Gordon S, et al. 2007. Dectin-1 is required for $\beta$-glucan recognition and control of fungal infection. Nat Immunol 8: 31-38.

Thomas PG, Dash P, Aldridge JR Jr, Ellebedy AH, Reynolds C, Funk AJ, Martin WJ, Lamkanfi M, Webby RJ, Boyd KL, et al. 2009. The intracellular sensor NLRP3 mediates key innate and healing responses to influenza A virus via the regulation of caspase-1. Immunity 30: 566-575.

Tkalcevic J, Novelli M, Phylactides M, Iredale JP, Segal AW, Roes J. 2000. Impaired immunity and enhanced resistance to endotoxin in the absence of neutrophil elastase and cathepsin G. Immunity 12: 201-210.

Tomalka J, Ganesan S, Azodi E, Patel K, Majmudar P, Hall BA, Fitzgerald KA, Hise AG. 2011. A novel role for the NLRC4 inflammasome in mucosal defenses against the fungal pathogen Candida albicans. PLoS Pathog 7: e1002379.

Urban CF, Reichard U, Brinkmann V, Zychlinsky A. 2006. Neutrophil extracellular traps capture and kill Candida albicans yeast and hyphal forms. Cell Microbiol 8: 668676.

Urban CF, Ermert D, Schmid M, Abu-Abed U, Goosmann C, Nacken W, Brinkmann V, Jungblut PR, Zychlinsky A. 2009. Neutrophil extracellular traps contain calprotectin, a cytosolic protein complex involved in host defense against Candida albicans. PLoS Pathog 5: e1000639.

van Bruggen R, Drewniak A, Jansen M, van Houdt M, Roos D, Chapel H, Verhoeven AJ, Kuijpers TW. 2009. Complement receptor 3, not Dectin-1, is the major receptor on human neutrophils for $\beta$-glucan-bearing particles. Mol Immunol 47: 575-581.

Van der Graaf CAA, Netea MG, Morre SA, Den Heijer M, Verweij PE, Van der Meer JWM, Kullberg BJ. 2006. Tolllike receptor 4 Asp299Gly/Thr399Ile polymorphisms are a risk factor for Candida bloodstream infection. Eur Cytokine Netw 17: 29-34.

van de Veerdonk FL, Marijnissen RJ, Kullberg BJ, Koenen HJPM, Cheng S-C, Joosten I, van den Berg WB, Williams DL, van der Meer JWM, Joosten LAB, et al. 2009. The macrophage mannose receptor induces IL-17 in response to Candida albicans. Cell Host Microbe 5: 329-340.

van de Veerdonk FL, Kullberg BJ, Verschueren IC, Hendriks T, van der Meer JWM, Joosten LAB, Netea MG. 2010 Differential effects of IL-17 pathway in disseminated Candidiasis and Zymosan-induced multiple organ failure. Shock 34: 407-411. 
Vautier S, Drummond RA, Redelinghuys P, Murray GI, MacCallum DM, Brown GD. 2012. Dectin-1 is not required for controlling Candida albicans colonization of the gastrointestinal tract. Infect Immun 80: 4216-4222.

Viriyakosol S, Jimenez Mdel P, Gurney MA, Ashbaugh ME, Fierer J. 2013. Dectin-1 is required for resistance to Coccidioidomycosis in mice. MBio 4: e00597.

Vlachos C, Schulte BM, Magiatis P, Adema GJ, Gaitanis G. 2012. Malassezia-derived indoles activate the aryl hydrocarbon receptor and inhibit Toll-like receptor-induced maturation in monocyte-derived dendritic cells. Brit $J$ Dermatol 167: 496-505.

von Bernuth H, Picard C, Jin Z, Pankla R, Xiao H, Ku C-L, Chrabieh M, Mustapha IB, Ghandil P, Camcioglu Y, et al. 2008. Pyogenic bacterial infections in humans with MyD88 deficiency. Science 321: 691-696.

Wagener J, Schneider JJ, Baxmann S, Kalbacher H, Borelli C Nuding S, Küchler R, Wehkamp J, Kaeser MD, Mailänder-Sanchez D, et al. 2013. A peptide derived from the highly conserved protein GAPDH is involved in tissue protection by different antifungal strategies and epithelial immunomodulation. J Invest Dermatol 133: 144-153.

Walev I, Reske K, Palmer M, Valeva A, Bhakdi S. 1995. Potassium-inhibited processing of IL- $1 \beta$ in human monocytes. EMBO J 14: 1607-1614.

Walker JA, Barlow JL, McKenzie ANJ. 2013. Innate lymphoid cells-How did we miss them? Nat Rev Immunol 13: $75-87$

Weindl G, Wagener J, Schaller M. 2010. Epithelial cells and innate antifungal defense. J Dent Res 89: 666-675.

Wells CA, Salvage-Jones JA, Li X, Hitchens K, Butcher S, Murray RZ, Beckhouse AG, Lo YLS, Manzanero S, Cobbold C, et al. 2008. The macrophage-inducible C-type lectin, Mincle, is an essential component of the innate immune response to Candida albicans. J Immunol 180: 7404-7413.

Werner JL, Metz AE, Horn D, Schoeb TR, Hewitt MM, Schwiebert LM, Faro-Trindade I, Brown GD, Steele C. 2009. Requisite role for the Dectin-1 $\beta$-glucan receptor in pulmonary defense against Aspergillus fumigatus. J Immunol 182: 4938-4946.

Werner JL, Gessner MA, Lilly LM, Nelson MP, Metz AE, Horn D, Dunaway CW, Deshane J, Chaplin DD, Weaver CT, et al. 2011. Neutrophils produce interleukin 17A (IL17A) in a Dectin-1- and IL-23-dependent manner during invasive fungal infection. Infect Immun 79: 3966-3977.

Wilson KP, Black JA, Thomson JA, Kim EE, Griffith JP, Navia MA, Murcko MA, Chambers SP, Aldape RA, Raybuck SA, et al. 1994. Structure and mechanism of interleukin-1 $\beta$ converting enzyme. Nature 370: 270-275.

Wüthrich M, Gern B, Hung CY, Ersland K, Rocco N, PickJacobs J, Galles K, Filutowicz H, Warner T, Evans M, et al. 2011. Vaccine-induced protection against 3 systemic mycoses endemic to North America requires Th17 cells in mice. J Clin Invest 121: 554-568.

Wüthrich M, Deepe G, Klein B. 2012. Adaptive immunity to fungi. Annu Rev Immunol 30: 115-148.

Yamasaki S, Matsumoto M, Takeuchi O, Matsuzawa T, Ishikawa E, Sakuma M, Tateno H, Uno J, Hirabayashi J, Mikami Y, et al. 2009. C-type lectin Mincle is an activating receptor for pathogenic fungus, Malassezia. Proc Nat Acad Sci 106: 1897-1902.

Yano J, Kolls JK, Happel KI, Wormley F, Wozniak KL, Fidel PL. 2012. The acute neutrophil response mediated by S100 alarmins during vaginal Candida infections is independent of the Th17-pathway. PLoS ONE 7: e46311. 


\section{$\&_{\mathrm{CSH}}^{\infty} \&$ Cold Spring Harbor

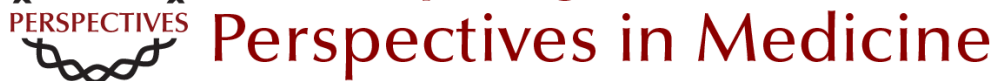

\section{Innate Defense against Fungal Pathogens}

Rebecca A. Drummond, Sarah L. Gaffen, Amy G. Hise and Gordon D. Brown

Cold Spring Harb Perspect Med 2015; doi: 10.1101/cshperspect.a019620 originally published online November 10, 2014

\section{Subject Collection Human Fungal Pathogens}

\section{Evolutionary Perspectives on Human Fungal Pathogens John W. Taylor}

Black Molds and Melanized Yeasts Pathogenic to Humans Anuradha Chowdhary, John Perfect and G. Sybren de Hoog

Fungal Pathogens: Survival and Replication within Macrophages Andrew S. Gilbert, Robert T. Wheeler and Robin C. May

Innate Defense against Fungal Pathogens Rebecca A. Drummond, Sarah L. Gaffen, Amy G. Hise, et al.

Antifungal Pharmacokinetics and Pharmacodynamics Alexander J. Lepak and David R. Andes

Human Fungal Pathogens of Mucorales and Entomophthorales

Leonel Mendoza, Raquel Vilela, Kerstin Voelz, et al.

Functional Profiling of Human Fungal Pathogen Genomes

Alexi I. Goranov and Hiten D. Madhani

Aspergillus fumigatus and Related Species Janyce A. Sugui, Kyung J. Kwon-Chung, Praveen R. Juvvadi, et al.
Thermally Dimorphic Human Fungal Pathogens-Polyphyletic Pathogens with a Convergent

Pathogenicity Trait Anita Sil and Alex Andrianopoulos

Mechanisms of Antifungal Drug Resistance Leah E. Cowen, Dominique Sanglard, Susan J. Howard, et al.

Treatment Principles for Candida and Cryptococcus Laura C. Whitney and Tihana Bicanic

The Human Mycobiome Patrick C. Seed

Treatment Principles for the Management of Mold Infections

Dimitrios P. Kontoyiannis and Russell E. Lewis

Adaptive Immunity to Fungi Akash Verma, Marcel Wüthrich, George Deepe, et al.

The Candida Pathogenic Species Complex Siobhán A. Turner and Geraldine Butler

Fungal Morphogenesis Xiaorong Lin, J. Andrew Alspaugh, Haoping Liu, et al.

For additional articles in this collection, see http://perspectivesinmedicine.cshlp.org/cgi/collection/ 